Article

\title{
Toward a Stakeholder Perspective on Social Stability Risk of Large Hydraulic Engineering Projects in China: A Social Network Analysis
}

\author{
Zhengqi He ${ }^{1,2}$, Dechun Huang ${ }^{1,2}$, Changzheng Zhang ${ }^{1,2, *}$ and Junmin Fang ${ }^{1,2}$ \\ 1 Department of Finance, Business School of Hohai University, Nanjing 211100, China; \\ hzq1309@hhu.edu.cn (Z.H.); huangdechun@hhu.edu.cn (D.H.); fangjunmin@hhu.edu.cn (J.F.) \\ 2 Jiangsu Provincial Collaborative Innovation Center of World Water Valley and Water Ecological Civilization, \\ Nanjing 211100, China \\ * Correspondence: zcz@hhu.edu.cn; Tel.: +86-25-6851-4418
}

Received: 23 March 2018; Accepted: 14 April 2018; Published: 17 April 2018

\begin{abstract}
In China, large hydraulic engineering projects have made a great contribution to social economic development; at the same time, they also lead to social risks that affect social stability. The pluralism of stakeholders in large hydraulic engineering projects and the complex interrelationship among stakeholders are the important factors affecting social stability risk. Previous studies of social stability risk have mainly focused on risk identification and risk assessment, without considering the relationships among stakeholders and their linkages of risks. For large hydraulic engineering projects, this paper investigated the relevant risk factors and their interrelationships through a literature review and interviews that represented stakeholder perspectives. The key social stability risk factors were identified based on social network analysis. A multi-channel project financial system, a perfect interest compensation mechanism, an efficient prevention mechanism of group events, and a complete project schedule control system were proposed to mitigate the social stability risks. This study combined stakeholder management with risk management by using social network analysis, providing reference for the social stability risk management of large engineering projects in China.
\end{abstract}

Keywords: large hydraulic engineering projects; social stability risk; social network analysis; stakeholder analysis

\section{Introduction}

Hydraulic engineering is an important infrastructure of the national economy and social development, which has an irreplaceable role in aspects related to flood control safety, the rational use of water resources, ecological environment protection, and the promotion of national economic development. In 2017, the investment scale of China's hydraulic engineering projects under construction was over 900 billion RMB (RMB is the currency unit of China.), of which 16 large projects such as "the project of leading water from Chaoer River to Xiliao River" and "Water Diversion Project in central Yunnan" have been newly opened. Compared with general projects, large hydraulic engineering projects have several characteristics; these include long construction periods, a large scale of investment, a large number of stakeholders, and complicated issues. They also have a far-reaching impact on a country or a region's social and economic development, the ecological environment, and even political and military affairs. A large hydraulic engineering project is a complex system with many factors involved, ranging from immigrants, land acquisition and house demolition, conflicts of interest to social system reconstruction; the improper handling of any of these may easily lead to social conflicts, thus affecting social stability. 
Social stability risk refers to the social risks that accumulate to a degree in the social system, causing social disorder and social environmental disharmony. The construction and properties of large hydraulic engineering projects inevitably impacts the regional and national society-economy-ecology system, especially in relation to land acquisition and house demolition issues and environment damage issues. These are also accompanied by great social risks that have a wide spread of aspects and a large range of influence. They may also cause a catastrophic disaster, which has always been an inducing factor to social stability risk. Social stability risk is the major management object for the government to "maintain stability", which is an important measure to maintain sustainable economic development and social stability. In March 2011, the Chinese Government made it a priority to "establish [the] social stability risk assessment mechanism of large engineering projects and major policy decisions", and then promulgated the report titled "Measures of Social Stability Risk Assessment of Large Investment in the Fixed Assets" in the following year. The Chinese Government re-emphasized the need to "implement the social stability risk assessment mechanism of major policy decisions to prevent and defuse social contradiction" in their "Report on the Work of the Government (2015)", and proposed that they "must take tough steps to forestall and defuse major risks" and "improve mechanisms for preventing and defusing social tensions" in 2017. All of this shows that the government has always placed a high value on the social stability risk of large engineering projects at all levels and across all social groups, and that it has become an important part in the assessment of engineering projects.

In China, the social stability risk is usually relevant to group events, social conflicts, and violent resistance. Since conflicts of interest among different stakeholders have become the primary sources of social stability risks, sufficient attention should be paid to the relationship between stakeholders and social stability risk. In addition, previous studies have not fully considered the interactions among different social stability risk factors, which may lead to the invalid management of social stability risk. Therefore, from the perspective of stakeholders and on a network basis, this paper considers the interactions among risk factors, investigates the social stability risk factors and their interactions by using social network analysis, and combines stakeholder management with social stability risk management. These interactions provide important references for the social stability risk management of the existing large engineering projects.

\section{Literature Review}

\subsection{Stakeholder Research of Engineering Projects}

The Stanford Institute defined the stakeholder as the subject that is vital to the survival of an organization in 1963. In the classic work "Strategic Management: A stakeholder approach", Freeman specifically came up with stakeholder theory for the first time, regarding a stakeholder as an individual or a group that has an influence on the realization of an organization's goals or can be affected by the realization of an organization's goals and its progress [1]. Since then, many scholars have enriched stakeholder theories. Bryson [2] regarded stakeholders as individuals or groups that have rights to an organization's resources and output, and that are also deeply influenced by the organization's output. Scholes and Johnson [3] defined stakeholders as individuals or groups that reach goals by relying on organization, which in turn are relied on by the organization. From the perspective of stakeholder individuals, PMI defined a stakeholder as "individuals and organizations who are active, or have double-faced impact on their interests in the project process" [4]. Due to the broad conceptualization of a stakeholder, there are different criteria for the classification of a stakeholder. Freeman classified the stakeholder from three different perspectives of ownership, economic dependence, and social interest. Charkham [5] categorized the stakeholder as either a contract stakeholder or a community stakeholder, based on the contractual relationship. According to the close relationship between people and enterprises, Clarkson classified the stakeholder into three types: core stakeholder, strategic stakeholder, and environment stakeholder [6]. 
At present, a large number of scholars have applied stakeholder management to the management of engineering projects, such as urban regeneration projects [7], construction projects [8], protection projects [9], and so on. Mok, Shen, and Yang [10] analyzed the research development of stakeholder management of construction projects by reviewing published articles, and identified four topics; these include interests and influences, the management process, analysis methods, and engagement. Bal, Bryde, Fearon, and Ochieng [11] argued that the stakeholder process should include identification, prioritization, managing, and so on. The basic issue is how to define the stakeholder. Gradually, two views are formed. One is to start with the relationship between the project and the stakeholders, which is usually defined by the verb "influence" $[12,13]$. The other is to define what the qualifications of the stakeholders are through the use of explicit descriptive terms such as "interest", "contribution", "risk", etc., which can identify project stakeholders more clearly [14,15]. Pinto and Morris [16] classified project stakeholders as internal stakeholders and external stakeholders. Callan, Sieimieniuch, and Sinclair [17] categorized stakeholders as managers, executives, responsibility advisors, and general advisors. Lin, Ho, and Shen [18] identified stakeholder categories by ranking the rights in the construction projects. For the concrete method of stakeholder classification, many methods have been proposed, such as the multidimensional subdivision method [19], the social network analysis method [20], and stakeholder mapping [21]. After long-term development, stakeholder management is usually used to handle complex stakeholder situations in large hydraulic engineering projects to reduce stakeholder conflicts and manage stakeholder behavior.

\subsection{Social Stability Risk Research on Large Hydraulic Engineering Projects}

Before the 1970s, the research on the impact of engineering projects by international scholars mainly focused on the economic aspects, and the theoretical basis was classical economics [22,23]. With the social problems triggered by the engineering projects getting more and more attention, the international scholars have proposed that both economic development and social impact should be emphasized during research studies on the influence of engineering projects, and it has been generally accepted. Since then, the social impact assessment has turned into one of the important composed departments of engineering projects assessment, and a complete Social Impact Assessment (SIA) has been gradually formed [24,25]. Becker [26] defined the social impact assessment of engineering projects and its evaluation perspectives, laying a theoretical foundation for social impact assessment. The World Bank introduced a social impact assessment in the 1970s, and for the first time in 1984, social assessment was considered as "an important part of project feasibility study" [27], and formed five cut-in points for social impact assessment, which included agency roles and behaviors, stakeholders, social risks, and so on [28]. At the same time, SIA has been carried out in several ways in many countries and international organizations, such as the United States, Japan, the Asian Development Bank, and the African Development Bank.

The social stability risk of large hydraulic engineering projects is the concentrated outbreak of social risks caused by the project's construction, thus causing social instability. The social risk research on engineering projects is mainly based on the research on "risk" by sociologists such as Beck [29] and Giddens [30]. Hu, Chan, Le, and Jin [31] pointed out that the social risk of engineering projects mainly referred to the social risk caused by stakeholders' different responses to specific issues, leading to conflicts between policymakers and affected stakeholders, and affecting social stability risk. Shi, Liu, Zuo, Pan, and Ma [32] studied the social risk management issues of infrastructure projects, and put forth policies and recommendations to prevent and mitigate the consequences of social risk events. Through a typical case study, Liu, Zhu, Wang, and Huang [33] explored how to determine the social risks from the perspective of grassroots governments, and then put forward a series of solutions to eliminate the social risks.

In recent years, with the Chinese government attaching great importance to the management of social stability risk, the relevant research directions have gradually become a hot topic. Chinese scholars have mainly focused on two aspects; one was to establish an index system and model for the 
social stability risk assessment of engineering projects based on different perspectives and methods. Feng and Zhang [34] classified the risk factors as procedural risk, cognitive risk, and frictional risk, and based on these three factors, they constructed an assessment index system for social stability risk. Xiao, Zhu, and Liu [35] built a non-intervention online assessment model to assess the social stability risks of large engineering projects by monitoring the local people's risk perception and negative emotions. On the other hand, it mainly proposed specific management measures to the social stability risk caused by large engineering projects [36,37]. Sun considered the issue of social stability in relation to the Three Gorges in his research regarding the social stability risk of large hydraulic engineering projects [38]. He believed that due to the construction of the Three Gorges Hydraulic Engineering project, it would take a long-term process to reconstruct the social humanistic environment, and the involuntary immigrant mentality may undergo complicated changes under the influence of the market economy. Based on the vulnerability of the social system, scholars constructed an assessment model for the social stability risks of large hydraulic construction, which consists of social risk exposure, public risk perception, and social coping ability, and proposed effective measures to control the social stability risk $[39,40]$. Focused on the construction and operation characteristics of a certain river course in China's Huaihe River, Yu, Sun, and Zhou [41] analyzed the social stability risk from the possibilities of group ideology and behavior, and built the whole process risk control system of precaution, process control, and afterward improvement.

\subsection{Social Network Analysis: A New Perspective to Solve Project Risk}

The term 'social network' refers to a relatively stable relationship system formed by interactions among individuals, organizations, and even the whole society, which focuses on the interaction and contact among individuals. First appearing in the 1930s, social network analysis (SNA) is a kind of quantitative analysis method based on graph theory and the mathematical method [42,43], with the three theory branches of strength and weakness relationship theory [44], structural hole theory [45], and social capital theory [46]. It has been widely applied in the fields of natural science, sociology, statistics, psychology, information science, economy, and the management of enterprises and organization management $[47,48]$.

In the 1990s, social network analysis was introduced into the management of engineering projects, primarily to analyze the complex relationships among project participants [49,50]. Ferriani [51] argued that the project organization itself was made up of many stakeholders, and the transmission of information and resources among the organizations is based on the network structure that they formed. Therefore, the relationship among the project entities can be completely portrayed and analyzed by using social network technology. Liang, Yu, and Guo [52] proposed a SNA model to study the impact of stakeholders on project success. At present, the research of social network analysis in engineering project management can be divided into two categories according to node types. The first one was to use human objects as network nodes to analyze the relationship among project participants $[53,54]$. The second one was to consider non-human objects in the project as nodes to analyze their relationship $[55,56]$. Some scholars have used social network methods to research the risk of engineering projects based on the complex relationship among stakeholders. Yang and Zhou [57], Yu, Shen, Shi, Lai, Li, and Xu [58] respectively studied the green building projects and China's housing demolition projects, believing that the risks of engineering projects are closely related to the stakeholders, and the risks were interdependent, and then further put forward risk management measures. In this paper, we will apply social network analysis to investigate the social stability risk of large hydraulic engineering projects, as this approach links risk factors with their corresponding stakeholders and quantifies the interaction between these risk factors to provide a basis for social stability risk management. 


\section{Research Method}

The traditional research on social stability risk management generally follows the framework of risk identification, evaluation, analysis, and response, which can effectively identify and quantify risks, thus putting forward response measures. However, this framework doesn't consider the interaction among stakeholders and their impact on risk management. According to the literature review, SNA can be applied to deal with the complex risk relationships among stakeholders in engineering projects. Therefore, this study combines the traditional risk management framework with social network analysis to propose a social network analysis model for social stability risk management in large hydraulic engineering projects (Figure 1).

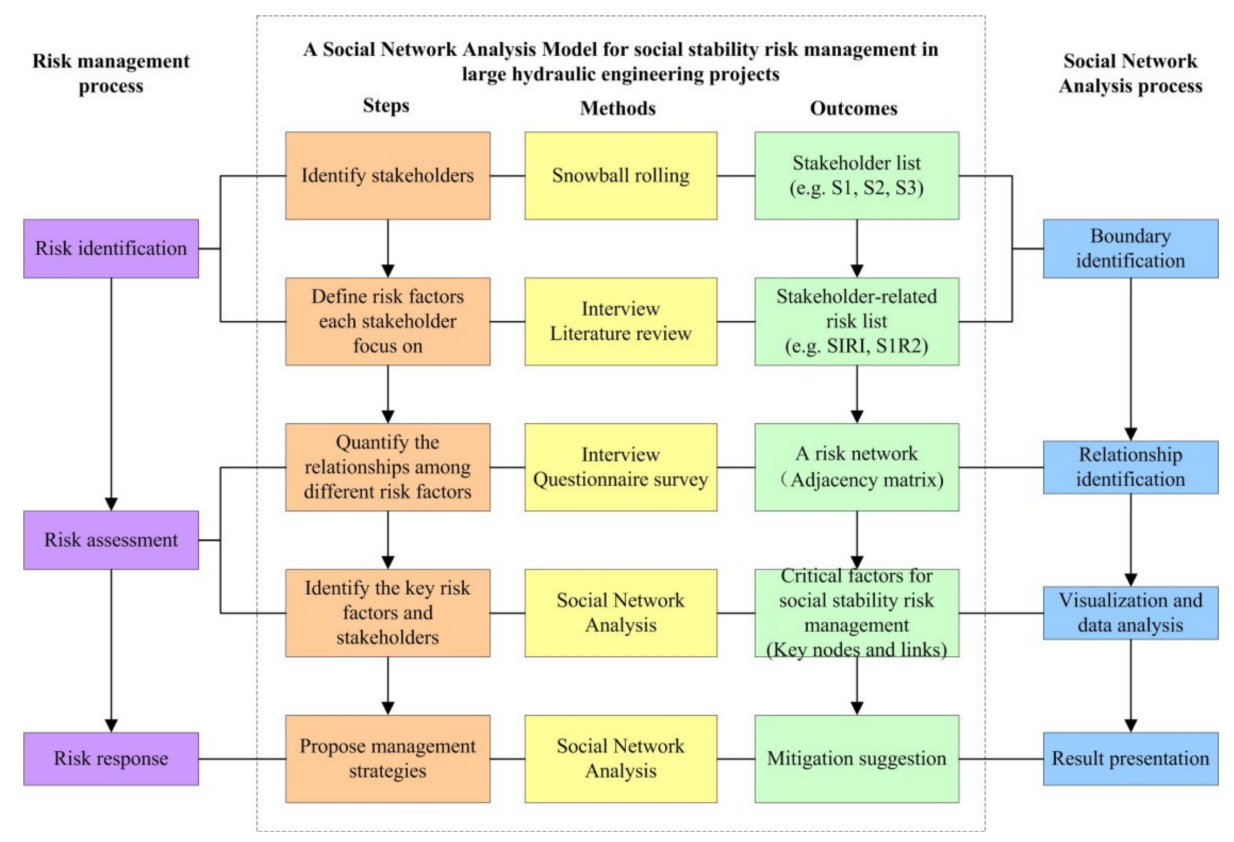

Figure 1. Framework of research method.

\subsection{Identification of Stakeholders and Risk Factors That Stakeholders Focus on}

In social network analysis, the primary thing is to determine the network nodes and their links. In this paper, there are three issues need to be solved: (1) How to identify the stakeholders of large hydraulic engineering projects? (2) How to determine the social stability risk factors of each stakeholder? (3) What is the relationship among these risk factors?

The first step is to identify the stakeholders. This paper used the snowball rolling method to determine the stakeholders in large hydraulic engineering projects. Relying on the cooperation among the author's research team and many water conservancy departments and water conservancy enterprises in China, we selected two representatives from a group of project developers and contractors who directly participated in the construction of many large hydraulic engineering projects. They both have many years of construction experience, and are very familiar with the relevant subjects of the projects. First of all, they were invited to provide a list of many stakeholders of large hydraulic engineering projects. Secondly, the stakeholders in the list were interviewed and invited to provide some other relevant stakeholders. Thirdly, these relevant stakeholders were invited to provide some subjects who influenced or were influenced by the project construction to obtain the stakeholders list. Finally, the collected list of stakeholders was fed back to the two respondents to identify the final stakeholder group list. Table 1 shows the eight identified stakeholders of the large hydraulic engineering project and is numbered as $\mathrm{Si}$ (where $\mathrm{i}=1$ to 8 ).

The second step is to determine the social stability risk factors of each stakeholder. First of all, by sorting out the relevant literature about the social stability risk of previous engineering projects, 
especially those large hydraulic engineering projects, we obtained a list of the social stability risk factors of large hydraulic engineering projects, which was fed back to the first two respondents for revising. Then, we interviewed the typical representatives of eight types of stakeholders. The interview mainly includes two aspects: (1) the roles and responsibilities of stakeholders; (2) the social stability risk factors that stakeholders are most concerned about. After arranging and analyzing the contents of the interviews, similar options were merged, and the contradictory options were interviewed again in order to reach a consensus. Through this process, 45 social stability risk factors faced by these eight stakeholder groups were finally identified and numbered as SiRj. The number of factors is shown in Table 1. Based on the different characteristics of risk factors, the 45 social stability risk factors were divided in seven categories: cost (C1), time (C2), environmental (C3), safety (C4), society (C5), technological (C6) and policy (C7).

Finally, the relationship among risk factors is quantified. This study solved the problem by sending a questionnaire. The respondents were asked to answer the question of whether there was any influence among the nodes, and clarify the direction of the influences in the survey. Then, respondents need to quantify the influences by answering two questions about the likelihood for the influence to happen and the intensity of the influences. We used the Likert scale to represent the answer (where " 5 " meant the highest standard and " 1 " meant the lowest standard). The final value of influences was obtained by multiplying the two answers. Finally, 381 linkages and 45 nodes were acquired by the results of the survey, forming the adjacency matrix.

In this paper, the determination of 45 risk factors and the relationships among these factors originated from interviews and questionnaires. These factors were directly given by the representative stakeholders based on their actual work experience. After summarizing the results of each respondent, we identified the final risk factors by discussing them with the representative respondents. Each respondent quantitatively indicated the influences among the risk factors by using the Linkert scale method. Then, we averaged the results of all of the respondents and obtained the final value, which showed the influences among the factors. Since all of the respondents in this paper were from the typical management department and construction departments of hydraulic engineering projects, they had rich experience and a better understanding of the social stability risk management of large hydraulic engineering projects. Thus, the risk factors identified by them are credible.

Table 1. Stakeholders list.

\begin{tabular}{clc}
\hline Stakeholder & \multicolumn{1}{c}{ Stakeholder Description } & Number of Risk Factors \\
\hline S1: Government & $\begin{array}{l}\text { The government agencies that the large hydraulic engineering } \\
\text { projects are located in }\end{array}$ & 7 \\
\hline S2: Project developers & $\begin{array}{l}\text { The engineering responsibility party of large hydraulic engineering } \\
\text { projects, which is responsible for project planning, funding raising, } \\
\text { construction, and operation }\end{array}$ & 8 \\
\hline S3: Contractors & $\begin{array}{l}\text { The enterprises who directly construct the large hydraulic } \\
\text { engineering projects (employed by S2) }\end{array}$ & 3 \\
\hline S4: Experts & $\begin{array}{l}\text { The scholars of water conservancy, engineering, } \\
\text { and environmental protection }\end{array}$ & 6 \\
\hline S5: Constructors & $\begin{array}{l}\text { The people who participate in the construction of large hydraulic } \\
\text { engineering projects }\end{array}$ & 5 \\
\hline S6: Relocated residents & $\begin{array}{l}\text { The residents who need to relocate to other places because of the } \\
\text { large hydraulic engineering projects }\end{array}$ \\
\hline S7: Local residents & $\begin{array}{l}\text { The residents who live in or near the large hydraulic } \\
\text { engineering projects }\end{array}$ \\
\hline S8: General public & $\begin{array}{l}\text { The social organizations and ordinary people that pay more } \\
\text { attention to the large hydraulic engineering projects }\end{array}$ & 3 \\
\hline
\end{tabular}

\subsection{Construction and Analysis of the Social Network Analysis Model}

In this step, we visualized and analyzed the network by using Ucinet. First, the adjacency matrix was input to Ucinet, and formed the network diagram by NetDraw. Then, we analyzed the overall network, calculating for network density and cohesion. Moreover, six indexes at the nodes level 
were measured, including the out-degree, degree difference of magnitude, ego network size, node betweenness centrality, out-status centrality, and brokerage. Finally, the link betweenness centrality was measured at the link level. The meaning and calculation method of all of these indexes can be found in references of Mok, Shen, Yang and Li [20] and Yang, Zou and Wang [59].

Finally, strategies of managing the social stability risk of large hydraulic engineering projects are put forward based on the SNA method. This study analyzes the results of seven indexes of network to determine the key social stability risk factors and their key interactions. We further summarize the key factors and their key interactions to put forward the corresponding risk mitigation suggestions.

\section{Results}

\subsection{Network Level Analysis}

There are 45 nodes and 381 links in the impact network of the social stability risk of large hydraulic engineering projects, as shown in Figure 2. The colors and shapes of the nodes represent the types of factors and stakeholder groups. The line between two nodes indicates that there is an interaction. The arrow from SiRj to SmRn indicates that SiRj has an impact on SmRn. The thickness of lines represents the degree of influence. The risk factors that have a great number of interactions are located in the network center, while the factors that have a small quantity of interactions are located at the network boundaries. As shown in Table 2, all of the risk factors are interdependent, reflecting the complexity of the social stability risk management of large hydraulic engineering projects. A large number of circle and square nodes occupy the center of the network, which also can be shown in Figure 2, indicating that government and project developers play the most important roles in the social stability risk network of large hydraulic engineering projects. The links among these nodes account for the majority of whole network. Due to the characteristics of large hydraulic engineering projects, government and project developers have become the direct participants, and have responsibility for controlling the possible risks of the projects, which may be the main reason why government and project developers are located in the network center. In addition, the technological and policy factors are at the edge of the network, which indicated that these two types of risk factors are not very important from the perspective of the stakeholders.

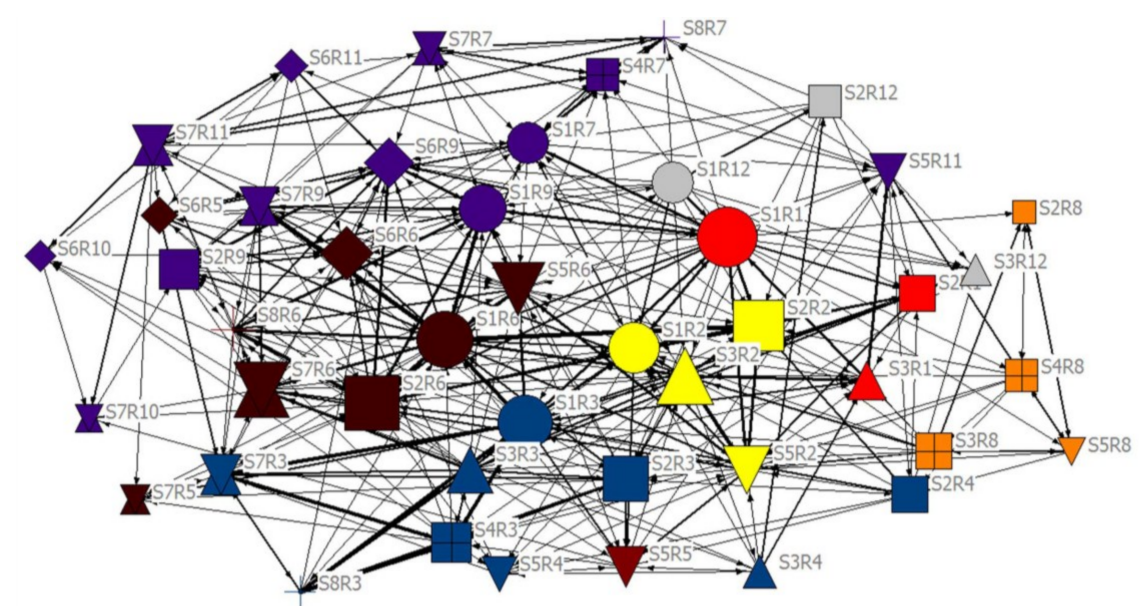

Figure 2. Stakeholder-related risk factors network. Note: (1) Node sizes denote node degree; (2) Node shapes denote types of stakeholders: Circles indicate government, Squares indicate project developers, Up Triangles indicate contractors, Boxes indicate experts, Down Triangles indicate constructors, Diamonds indicate relocated residents, Double Triangles indicate local residents, Pluses indicate the general public; (3) Node colors denote types of risk factors: Red indicates cost, Yellow indicates time, Blue indicates environmental, Brown indicates safety, Purple indicates society, Orange indicates technology, and Grey indicates policy. 
We quantified the overall network situation by calculating the network density. The network density is 0.1949 . We also calculated the network cohesion and average distance. The network cohesion is 0.536 , and the average distance is 2.199 walks. The results show that the network is dense, the nodes are concentrated, and the structure of the risk network is complicated.

\subsection{Node Level Analysis}

Table 2 presents the results of node level analysis, including the top 10 nodes of each indicator. This study focused on the top three nodes of each index. These nodes are considered to be the important social stability risk factors for large hydraulic engineering projects. As shown in Table 2, these eight key social stability risk factors are S1R1 (Project expenditures beyond the government's expectation), S1R2 (The project cannot be completed on time according to the government's requirements), S1R3 (The extent of environment pollution and ecological damage is beyond the government's expectation), S1R6 (The impact of group events triggered by the project on the government), S2R6 (The impact of group events triggered by the project on project developers), S3R2 (The risk that contractors cannot finish the project on time), S3R3 (The risk that contractors cannot control the environment pollution and ecological damage), S5R6 (The impact of group events triggered by the project on the constructors). These key nodes have large interactions with many adjacent nodes, thus affecting the social stability risk of large hydraulic engineering projects.

Table 2. The top 10 social stability risk factors in the node level results.

\begin{tabular}{|c|c|c|c|c|c|c|}
\hline Rank & Risk ID & Out-Degree & Risk ID & $\begin{array}{l}\text { Degree Difference } \\
\text { Magnitude }\end{array}$ & Risk ID & Ego Network Size \\
\hline 1 & S1R1 & 24 & S1R1 & 17 & S1R1 & 26 \\
\hline 2 & S1R3 & 20 & S1R3 & 13 & S1R6 & 24 \\
\hline 3 & S1R6 & 17 & S3R3 & 12 & S3R2 & 24 \\
\hline 4 & S3R3 & 16 & S1R12 & 11 & S1R3 & 23 \\
\hline 5 & S2R3 & 14 & S7R11 & 9 & S2R6 & 23 \\
\hline 6 & S5R6 & 13 & S2R3 & 7 & S5R6 & 22 \\
\hline 7 & S1R2 & 13 & S3R8 & 7 & S1R2 & 21 \\
\hline 8 & S1R12 & 13 & S4R8 & 6 & $\mathrm{~S} 2 \mathrm{R} 2$ & 20 \\
\hline 9 & S7R11 & 13 & S2R4 & 5 & S6R6 & 20 \\
\hline 10 & S2R6 & 13 & S2R12 & 5 & S1R9 & 18 \\
\hline Rank & Risk ID & $\begin{array}{l}\text { Node Betweenness } \\
\text { Centrality }\end{array}$ & Risk ID & $\begin{array}{l}\text { Out-Status } \\
\text { Centrality }\end{array}$ & Risk ID & Brokerage \\
\hline 1 & S1R1 & 0.3080 & S1R1 & 1.5385 & S1R6 & 127 \\
\hline 2 & S2R6 & 0.1642 & S1R3 & 1.4493 & S5R6 & 127 \\
\hline 3 & S1R2 & 0.1404 & S1R2 & 1.2658 & S2R6 & 124 \\
\hline 4 & S5R6 & 0.1371 & S1R6 & 1.2658 & S1R1 & 117 \\
\hline 5 & S3R2 & 0.1345 & S1R12 & 1.2658 & S1R2 & 111 \\
\hline 6 & S6R6 & 0.1302 & S3R3 & 1.2658 & S3R2 & 108 \\
\hline 7 & S1R6 & 0.1294 & S2R3 & 1.2500 & S1R9 & 100 \\
\hline 8 & S6R9 & 0.1086 & S1R9 & 1.2195 & S1R3 & 85 \\
\hline 9 & S1R9 & 0.1082 & S5R6 & 1.1765 & S6R6 & 82 \\
\hline 10 & S4R3 & 0.1044 & S2R6 & 1.1765 & S2R2 & 68 \\
\hline
\end{tabular}

\subsection{Link Level Analysis}

In this step, we calculated the link betweenness centrality, which means the importance of an interaction in the entire network. Greater values indicated a more important relationship. This study analyzed every one of the 381 link betweenness centrality results, and found that value 30 was a turning point. Therefore, we selected the links that had a value over 30 as the key links, and by taking into account the eight key nodes identified in the previous section, 14 key links were finally found across all 381 interactions, as shown in Table 3. These 14 links were considered to be the key interactions of the risk network in large hydraulic engineering projects.

According to the social network analysis results, the next step is to have a deep analysis of key risk factors and key interactions, understand their practical meanings, and identify the major issues. As shown in Table 4, 14 key interactions can be grouped according to their practical meaning. 
For example, S6R9 $\rightarrow$ S1R6, S1R9 $\rightarrow$ S1R6, and S7R9 $\rightarrow$ S1R1 describe the interest compensation issues that each group of stakeholders focused on during the project construction. Therefore, these three key interactions were grouped together in order to determine one of the key issues regarding the social stability risk management of large hydraulic engineering projects: interest compensation issues of the affected people. According to the classification criteria, this paper finally identified four key issues: (1) the funding issues of the project construction; (2) the interest compensation issues of the affected people; (3) the impact of the group events caused by the projects; and (4) the time limit issues for the projects.

Table 3. The top 14 social stability risk factors in the link level results.

\begin{tabular}{cccccc}
\hline Rank & Link Code & Link Betweenness Centrality & Rank & Link Code & Link Betweenness Centrality \\
\hline 1 & S6R9 $\rightarrow$ S1R6 & 76.865 & 8 & S1R1 $\rightarrow$ S2R8 & 41.000 \\
2 & S1R2 $\rightarrow$ S1R1 & 51.686 & 9 & S1R6 $\rightarrow$ S1R12 & 37.074 \\
3 & S1R9 $\rightarrow$ S1R6 & 50.065 & 10 & S3R4 $\rightarrow$ S3R2 & 36.505 \\
4 & S7R9 $\rightarrow$ S1R1 & 44.920 & 11 & S3R1 $\rightarrow$ S1R1 & 35.456 \\
5 & S1R1 $\rightarrow$ S3R8 & 44.737 & 12 & S5R6 $\rightarrow$ S7R11 & 33.132 \\
6 & S1R1 $\rightarrow$ S4R8 & 42.948 & 13 & S7R5 $\rightarrow$ S2R6 & 32.949 \\
7 & S1R1 $\rightarrow$ S5R8 & 42.181 & 14 & S3R2 $\rightarrow$ S1R3 & 30.411 \\
\hline
\end{tabular}

Table 4. Major problems and key interactions.

\begin{tabular}{|c|c|c|}
\hline Major Problem & Key Interaction & Links Description \\
\hline \multirow{5}{*}{$\begin{array}{l}\text { 1. The funding issues of the } \\
\text { project construction }\end{array}$} & $\mathrm{S} 1 \mathrm{R} 1 \rightarrow \mathrm{S} 3 \mathrm{R} 8$ & $\begin{array}{l}\text { Project expenditures beyond the government's expectation may } \\
\text { lead contractors to have technical problems }\end{array}$ \\
\hline & $\mathrm{S} 1 \mathrm{R} 1 \rightarrow \mathrm{S} 4 \mathrm{R} 8$ & $\begin{array}{l}\text { Project expenditures beyond the government's expectation may } \\
\text { lead experts to query the advanced technology used in } \\
\text { the project }\end{array}$ \\
\hline & $\mathrm{S} 1 \mathrm{R} 1 \rightarrow \mathrm{S} 5 \mathrm{R} 8$ & $\begin{array}{l}\text { Project expenditures beyond the government's expectation may } \\
\text { lead constructors to have technical problems }\end{array}$ \\
\hline & $\mathrm{S} 1 \mathrm{R} 1 \rightarrow \mathrm{S} 2 \mathrm{R} 8$ & $\begin{array}{l}\text { Project expenditures beyond the government's expectation may } \\
\text { lead project developers not to adopt advanced technology }\end{array}$ \\
\hline & $\mathrm{S} 3 \mathrm{R} 1 \rightarrow \mathrm{S} 1 \mathrm{R} 1$ & $\begin{array}{l}\text { Cost overruns faced by contractors may cause project } \\
\text { expenditures beyond the government's expectation }\end{array}$ \\
\hline \multirow{3}{*}{$\begin{array}{l}\text { 2. The interest compensation } \\
\text { issues of the affected people }\end{array}$} & $\mathrm{S} 6 \mathrm{R} 9 \rightarrow \mathrm{S} 1 \mathrm{R} 6$ & $\begin{array}{l}\text { The interest compensation issues about relocated residents } \\
\text { haven't been handled well, and may increase the impact of } \\
\text { group events triggered by the project on the government }\end{array}$ \\
\hline & $\mathrm{S} 1 \mathrm{R} 9 \rightarrow \mathrm{S} 1 \mathrm{R} 6$ & $\begin{array}{l}\text { Government does not deal with the compensation issues of the } \\
\text { affected people, which may increase the impact of group events } \\
\text { triggered by the project on the government }\end{array}$ \\
\hline & $\mathrm{S} 7 \mathrm{R} 9 \rightarrow \mathrm{S} 1 \mathrm{R} 1$ & $\begin{array}{l}\text { The interest compensation issues of the relocated residents } \\
\text { haven't been handled well, which may cause project } \\
\text { expenditures beyond the government's expectation }\end{array}$ \\
\hline \multirow{3}{*}{$\begin{array}{l}\text { 3. The impact of the group } \\
\text { events caused by projects }\end{array}$} & $\mathrm{S} 1 \mathrm{R} 6 \rightarrow \mathrm{S} 1 \mathrm{R} 12$ & $\begin{array}{l}\text { The impact of group events triggered by the project on the } \\
\text { government may cause the government to change some } \\
\text { related policies }\end{array}$ \\
\hline & S5R6 $\rightarrow$ S7R11 & $\begin{array}{l}\text { The impact of group events triggered by the project on the } \\
\text { constructors may increase the unemployment risks of the } \\
\text { located residents }\end{array}$ \\
\hline & $\mathrm{S} 7 \mathrm{R} 5 \rightarrow \mathrm{S} 2 \mathrm{R} 6$ & $\begin{array}{l}\text { The health risk of the located residents may increase the impact } \\
\text { of the group events triggered by the project on } \\
\text { project developers }\end{array}$ \\
\hline \multirow{3}{*}{$\begin{array}{l}\text { 4. The time limit issues } \\
\text { for projects }\end{array}$} & $\mathrm{S} 1 \mathrm{R} 2 \rightarrow \mathrm{S} 1 \mathrm{R} 1$ & $\begin{array}{l}\text { The project cannot be completed on time according to the } \\
\text { government's requirements, which may cause project } \\
\text { expenditures beyond the government's expectations }\end{array}$ \\
\hline & $\mathrm{S} 3 \mathrm{R} 4 \rightarrow \mathrm{S} 3 \mathrm{R} 2$ & $\begin{array}{l}\text { The uncertainty of weather and the environment faced by the } \\
\text { contractors may increase the risk that the contractors cannot } \\
\text { finish the project on time }\end{array}$ \\
\hline & $\mathrm{S} 3 \mathrm{R} 2 \rightarrow \mathrm{S} 1 \mathrm{R} 3$ & $\begin{array}{l}\text { The risk that contractors cannot finish the project on time may } \\
\text { cause an extent of environment pollution and ecological damage } \\
\text { beyond the government's expectation }\end{array}$ \\
\hline
\end{tabular}




\section{Strategies of Managing the Social Stability Risk}

Based on the analysis of the four key issues, this paper presented four strategies for managing the social stability risk. As the government and project developers are major stakeholders in the development of large hydraulic engineering projects in China, these four strategies are mainly formulated for government and project developers. These risk management strategies include a multi-channel project financial system, a perfect interest compensation mechanism, an efficient prevention mechanism of group events, and a complete project schedule control system.

\subsection{Establish Multi-Channel Project Financial System}

According to Table 4, we can see that funding issues are very important in the construction of large hydraulic engineering projects. The funding issues easily lead to technical problems and project delay, causing contradictions among the funding, process, and quality under the construction. This greatly increases the uncertainty of the project, and affects the social stability of project construction area. At present, the main investment style of hydraulic engineering in China is still the gratuitousness government funding. The method of financing hydraulic engineering through the capital market is relatively simple, it mainly includes the lending policies of financial institutions and issuing bonds to itself. These ways all have small drawbacks, complicated handling procedures, and slow payment. In addition, because large hydraulic engineering projects have characteristics including long operating times and unmatched input-output ratios, and the products provided by water conservancy enterprises are beholden to both public and economic interests, financial institutions are reluctant to invest when they are not compensated by the government. Therefore, how to solve the project funding issues has become the primary task of social stability risk management.

In order to work out the project funding problems of large hydraulic engineering projects, firstly, we should improve the investment environment of water conservancy, create a fair market competition environment, and establish and improve laws and regulation systems. We also should increase the proportion of water conservancy investments in the government public finance budget to raise the sources of water conservancy funding. Secondly, several ways, such as issuing bonds and bills, should be fully used to raise funding in the financial market. The government can encourage financial institutions to invest in large hydraulic engineering projects by formulating policy and financial incentives. Thirdly, public-private cooperation should be strengthened to develop various investment modes such as Public-Private Partnership (PPP), Build-operate-transfer (BOT), and Build-transfer (BT). The government should also try to develop the securitization of water conservancy assets and integrate great assets to absorb social capital. In addition, advanced technology ought to be adopted during the construction to reduce costs and relieve the funding pressure of projects.

\subsection{Establish Perfect Interest Compensation Mechanism}

The second important factor of social stability risk management in large hydraulic engineering projects is the interest compensation issues of the affected people. The improper handling of interest compensation issues will directly lead to group events and increase the impact on the government and project developers. Meanwhile, it will increase the funding pressure on projects. In China, large hydraulic engineering projects should greatly promote regional development. However, the project construction often involves large-scale immigration. For the affected people, they have suffered blows related to the economy, their culture, and their emotions. At the same time, project construction is a game process among stakeholders (including the central government, the local government, project developers, current residents, and relocated residents). The process is full of conflicts, and greatly affects social stability. Therefore, a perfect interest compensation mechanism should be established to resolve conflict.

Due to the extreme complexity of interest compensation issues in large hydraulic engineering projects, current laws regarding land expropriation and house removal cannot solve the problems 
comprehensively and specifically. Thus, special laws about interest compensation in large hydraulic engineering projects should be promulgated to provide policy support. In addition, the current modes of one-time compensation and land relocation are too simplistic, ignoring the independent demands of affected people. Interest compensation modes with multiple compensation methods should be explored, such as social security, taxation, finance, and other forms of policy compensation. Establishing an investment system that combines government behavior with the market economy will establish a dominant position and ensure the discourse power of the affected people. An interest compensation standards formation mechanism that is linked with the market should also be established to measure the compensation standard on the basis of the market price.

\subsection{Establish Efficient Prevention Mechanism of Group Events}

The large hydraulic engineering projects inevitably cause conflicts of interest. The group events will appear when interest conflicts have not been handled well. In order to deal with the group events, large hydraulic engineering projects usually have to be postponed and suspended, and mitigate interest conflicts by increasing subsidies. These events increase the project cost as well as affect the project's progress. Moreover, outbreaks of group events not only directly affect the construction of large hydraulic engineering projects, they also destroy the social public order and threaten social security stability, causing unimaginable indirect economic losses. Therefore, how to effectively control the group events is also an important challenge in the social stability risk management of large hydraulic engineering projects.

First of all, an effective risk communication mechanism should be established so that stakeholders can agree on the risk perception. In the early stage of large hydraulic engineering projects, the government and project developers should enhance information disclosure, communicate with the public, and inform them of the risk level and prevention measures of the project in advance. It helps if the public have an objective cognition of the risks; at the same time, the government and project developers can keep abreast of located residents' and the general public's worries to provide early warnings. Secondly, the expression channel of interest demand should be improved. In the process of construction, we should broaden the channels for public participation regarding the assessment of the environment impact of projects, improve the petition mechanisms, strive to coordinate the interest relations among stakeholders, and avoid damaging interest expressions. Finally, new media should play a positive role. With the increasing popularity of the Internet, new media has become an important way for people to express their interest demands. The government should attach great importance to its function, and make full use of the positive propaganda role of new media in order to effectively control the unfair dissemination of public opinions on large hydraulic engineering projects.

\subsection{Establish Complete Project Schedule Control System}

As shown in Table 4, whether the large hydraulic engineering projects complete on time can directly affect the project cost. From the previous analysis, we know that the funding issues will increase the uncertainty of a project and form instability factors. On the other hand, the project progress control and quality control are a unity of opposites. Unreasonable progress management can easily cause quality problems, which will affect the safety of the project and cause public panic. Therefore, establishing a complete project schedule control system is also an important measure for the social stability risk management of large hydraulic engineering projects.

Large hydraulic engineering projects belong to a huge complex engineering, and include many single projects. The cohesion relations among each single project are very complicated, which increase the difficulty of project schedule control. First of all, a scientific and reasonable feasibility study and planning should be carried out at the beginning of the projects. We should complete the impact assessment, which ought to include social, environment, economic, and security aspects, so as to reduce the possible time limit impact caused by unreasonable decisions. On the other hand, project developers shall formulate schedule management plans for different stages of design, 
bid invitation and construction, and adopt comprehensive schedule management measures by combining various measures such as economic measures, technical measures, and contractual measures. Project developers should often check whether the actual progress is carried out as required in the process of construction, analyze the deviation situation, and take remedial measures to accomplish the project control objectives and ensure that the project is completed on time.

\section{Conclusions}

Based on social network analysis theory and the traditional risk management framework, this paper explores the main challenges faced by stakeholders through the analysis of the social stability risk factors and their interactions, which provides a new perspective for the social stability risk management of large hydraulic engineering projects. Previous studies have mainly regarded the risk factors of each stakeholder as relatively independent, but their complex interactions are the main reasons for the social stability risk. These interactions may cause other problems to break out and create a chain reaction when a problem arises but cannot be solved, which will further lead to group events and cause social stability risk. This study obtained a risk list that included 45 factors based on the literature review and interviews. The key risk factors and interactions that directly or indirectly have a significant impact on other factors were identified based on social network analysis. We found that the government and project developers were the most important stakeholders, and the project funding issues, interest compensations issues, group events impacting issues, and project limit time issues were the main factors that cause social stability risk. Therefore, this paper proposed risk management strategies for government and project developers, which included the construction of a multi-channel project financial system, a perfect interest compensation mechanism, an efficient prevention mechanism of group events, and a complete project schedule control system, so as to mitigate the social stability risk. This study can help the managers of large hydraulic engineering projects manage and resolve social stability risks during construction. On the one hand, the 45 risk factors we have obtained can be directly used as a managers' risk list to identify potential social stability risks and formulate appropriate risk response plans. On the other hand, the SNA model that was established quantified the complex relationship between risk factors and stakeholders, and identified the key risks from network and system perspectives. It can effectively solve the social stability risk problems that are related to stakeholders, and establish a close contact between stakeholder management and the social stability risk management of engineering projects.

There are three limitations to this study. Firstly, although the chain referral sampling was adopted in this paper, it is still difficult to attract all of the stakeholders to participate. In particular, some of the stakeholders probably did not provide real data out of secrecy and anonymity concerns. Secondly, due to the complexity of large hydraulic engineering projects, the survey cannot include all of the potential social stability risk factors. Some new risk factors or network structures may arise in the actual process. Lastly, the four risk management strategies that were proposed in this paper have not been yet simulated, so their practicality and effectiveness cannot be evaluated. Future study will be carried out in three aspects. (1) First, there are many ways to determine the factors and their mutual relationships. The grey incidence analysis based on the grey systems theory is a common method that has been applied to social network analysis. The relationships among some factors in the online social network have been analyzed by calculating the degree of grey incidence, and a comparative study has been conducted in Romania and Thailand [60]. The grey incidence analysis can be used to describe the strength, size, and order of the relationships between factors by calculating the absolute degree, the relative degree, and the synthetic degree. Then, we can remove the indicators that have a smaller influence and find out the main relationships according to the degree of grey incidence. Combining the grey systems theory with social network analysis is a very worthwhile direction; it can play a great role, especially when the indicators are few and information is scarce. In future research, we will introduce grey systems theory and optimize the indicators by combining them with questionnaires, interviews, and other methods, thus providing a new idea for the social stability risk management of 
large hydraulic engineering projects; (2) We should expand the scope of the investigation and study more cases to collect the stakeholders and social stability risk factors in a wider scope and improve the SNA model; (3) The simulation analysis of the risk management strategies should be carried out. We should suppose that the appropriate risk management strategies have been taken, remove the corresponding nodes and links, and then analyze the characteristics and quantify the effectiveness of the risk management strategies based on the new network to provide support for the optimization of risk management strategies.

Acknowledgments: This study is sponsored by the National Natural Science Foundation of China (71573072; 71603070), the National Social Science Foundation of China (14BSH021) and the Postgraduate Research Innovation Program of Jiangsu Province (KYZZ16_0264).

Author Contributions: Z.H. and C.Z. built the framework of the study; D.H. and C.Z. contributed to the interview and questionnaire; Z.H. and J.F. performed the data collection; Z.H. and D.H. had a lot of works on the analysis of data; Z.H. wrote the paper.

Conflicts of Interest: The authors declare no conflict of interest.

\section{References}

1. Freeman, R.E. Strategic Management: A Stakeholder Approach; Pitman: Boston, MA, USA, 1984.

2. Bryson, J.M. Strategic Planning for Public and Nonprofit Organizations: A Guide to Strengthening and Sustaining Organizational Achievement; Jossey-Bass: San Francisco, CA, USA, 1995.

3. Scholes, K.; Johnson, G. Exploring Public Sector Strategy; Pearson Education Inc.: New York, NY, USA, 2001.

4. PMI. Project Management Body of Knowledge; Project Management Institute: Newtown Square, PA, USA, 1996.

5. Charkham, J.P. Corporate governance: Lessons from abroad. Eur. Bus. J. 1992, 4, 8.

6. Clarkson, M.E. A stakeholder framework for analyzing and evaluating corporate social performance. Acad. Manag. Rev. 1995, 20, 92-117.

7. Radulescu, C.M.; Stefan, O.; Radulescu, G.M.; Radulescu, A.T.; Radulescu, M.V. Management of Stakeholders in Urban Regeneration Projects. Case Study: Baia-Mare, Transylvania. Sustainability 2016, 8, 238. [CrossRef]

8. Oppong, G.D.; Chan, A.P.; Dansoh, A. A review of stakeholder management performance attributes in construction projects. Int. J. Proj. Manag. 2017, 3, 1037-1051. [CrossRef]

9. Boumaour, A.; Grimes, S.; Brigand, L.; Larid, M. Integration process and stakeholders' interactions analysis around a protection project: Case of the National park of Gouraya, Algeria (South-western Mediterranean). Ocean Coast. Manag. 2018, 153, 215-230. [CrossRef]

10. Mok, K.Y.; Shen, G.Q.; Yang, J. Stakeholder management studies in mega construction projects: A review and future directions. Int. J. Proj. Manag. 2015, 33, 446-457. [CrossRef]

11. Bal, M.; Bryde, D.; Fearon, D.; Ochieng, E. Stakeholder engagement: Achieving sustainability in the construction sector. Sustainability 2013, 5, 695-710. [CrossRef]

12. Gibson, K. The moral basis of stakeholder theory. J. Bus. Ethics 2000, 26, 245-257. [CrossRef]

13. Yang, J.; Shen, G.Q.; Ho, M.; Drew, D.S.; Xue, X. Stakeholder management in construction: An empirical study to address research gaps in previous studies. Int. J. Proj. Manag. 2011, 29, 900-910. [CrossRef]

14. Olander, S. Stakeholder impact analysis in construction project management. Constr. Manag. Econ. 2007, 25, 277-287. [CrossRef]

15. Walker, D.H.; Bourne, L.M.; Shelley, A. Influence, stakeholder mapping and visualization. Constr. Manag. Econ. 2008, 26, 645-658. [CrossRef]

16. Pinto, J.K.; Morris, P.W. The Wiley Guide to Managing Projects; Wiley: Hoboken, NJ, USA, 2004.

17. Callan, K.; Sieimieniuch, C.; Sinclair, M. A case study example of the role matrix technique. Int. J. Proj. Manag. 2006, 24, 506-515. [CrossRef]

18. Lin, X.; Ho, C.M.; Shen, G.Q. Who should take the responsibility? Stakeholders' power over social responsibility issues in construction projects. J. Clean. Prod. 2017, 154, 318-329. [CrossRef]

19. Mitchell, R.K.; Agle, B.R.; Wood, D.J. Toward a theory of stakeholder identification and salience: Defining the principle of who and what really counts. Acad. Manag. Rev. 1997, 22, 853-886. 
20. Mok, K.Y.; Shen, G.Q.; Yang, R.J.; Li, C.Z. Investigating key challenges in major public engineering projects by a network-theory based analysis of stakeholder concerns: A case study. Int. J. Proj. Manag. 2017, 35, 78-94. [CrossRef]

21. Reed, M.S. Stakeholder participation for environmental management: A literature review. Biol. Conserv. 2008, 141, 2417-2431. [CrossRef]

22. Little, I.M.D.; Mirrlees, J.A. Manual of industrial project analysis in developing countries. J. Econ. Lit. 1972, 10, 81-83.

23. Marglin, S.A.; Sen, A. Guidelines for Project Evaluation; United Nations Industrial Development Organization: New York, NY, USA, 1972.

24. Schnaiberg, A. The environment: From Surplus to Scarcity; Oxford University Press: Oxford, UK, 1980.

25. Tilt, B.; Braun, Y.; He, D. Social impacts of large dam projects: A comparison of international case studies and implications for best practice. J. Environ. Manag. 2009, 90, S249-S257. [CrossRef] [PubMed]

26. Becker, H.A. Social Impact Assessment. Eur. J. Oper. Res. 2011, 128, 311-321. [CrossRef]

27. Dani, A. Social Analysis Sourcebook: Incorporating Social Dimensions into Bank-Supported Projects; The World Bank Social Development Department: Washington, DC, USA, 2013.

28. Krueger, R.A.; Casey, M.A.; Donner, J.; Kirsch, S.; Maack, J.N. Social analysis: Selected tools and techniques. Soc. Dev. Pap. 2001, 36, 50-87.

29. Beck, U. Risk Society: Towards a New Modernity; Sage: Thousand Oaks, CA, USA, 1992.

30. Giddens, A. Risk Society: The Context of British Politics. The Politics of Risk Society; Polity Press: Cambridge, UK, 1988; pp. 23-34.

31. Hu, Y.; Chan, A.P.; Le, Y.; Jin, R.Z. From construction megaproject management to complex project management: Bibliographic analysis. J. Manag. Eng. 2013, 31. [CrossRef]

32. Shi, Q.; Liu, Y.; Zuo, J.; Pan, N.; Ma, G. On the management of social risks of hydraulic infrastructure projects in China: A case study. Int. J. Proj. Manag. 2015, 33, 483-496. [CrossRef]

33. Liu, Z.Z.; Zhu, Z.W.; Wang, H.J.; Huang, J. Handling social risks in government-driven mega project: An empirical case study from West China. Int. J. Proj. Manag. 2016, 34, 202-218. [CrossRef]

34. Feng, Z.Z.; Zhang, Y. The causes and classification of social stability risk of large projects. Adm. Forum 2017, 1, 97-101. (In Chinese)

35. Xiao, Q.Y.; Zhu, Z.W.; Liu, H.J. The Non-intervention and Online Mode for Social Stability Risk Evaluation in Major Projects. J. Public Adm. 2016, 9, 86-109. (In Chinese)

36. Zhu, Z.W.; Wang, Q.; Guo, X.S. Research on Social Stability Risk Evaluation of Engineering Projects-Factor Analysis based on the Public "Risk-Benefit" Perception Perspective. J. Xi'an Jiaotong Univ. Soc. Sci. 2016, 36, 61-68. (In Chinese)

37. Hu, X.M. Social Stability Risk Events of Sensitive Project-Process Model and Participat Action Logic. J. China Natl. School Adm. 2016, 2, 58-62. (In Chinese)

38. Sun, Y.M. Analysis on Major Social Problems in the Three Gorges Reservoir Area in Post-migration Period: Their Causes and the Suggestion for Their Solution. China Soft Sci. 2011, 6, 24-33. (In Chinese)

39. Huang, D.C.; Zhang, C.Z.; Lall, U.; Xu, M. Study on the Social Stability Risk of Large Hydraulic Project. China Popul. Resour. Environ. 2013, 23, 89-95. (In Chinese)

40. Wang, B.; Huang, D.C.; Hua, J.; Zhang, C.Z. Research on the Social Stability Risk Assessment and Empirical Analysis of Hydraulic Engineering Construction. China Popul. Resour. Environ. 2015, 25, 149-154. (In Chinese)

41. Yu, W.X.; Sun, B.; Zhou, Y. Social Stability Risk Assessment and Control of Large-Scale River Course Projects: Taking Huai River RH Project as an Example. J. Hohai Univ. Philos. Soc. Sci. 2016, 4, 71-76. (In Chinese)

42. Moreno, J.L. Who Shall Survive? Foundations of Sociometry, Group Psychotherapy, and Sociodrama; Beacon House Inc.: Beacon, NY, USA, 1934.

43. Lewin, K. Principles of Topological Psychology; McGraw-Hill: New York, NY, USA, 1976.

44. Granovetter, M.S. The strength of weak ties. Am. J. Sociol. 1973, 78, 1360-1380. [CrossRef]

45. Burt, R.S. Structural Holes: The Social Structure of Competition; Harvard University Press: Boston, MA, USA, 2009.

46. Bourdieu, P. The force of law: Toward a sociology of the juridical field. Hastings Law J. 1986, 38, 805-850.

47. Bossche, P.; Segers, M. Transfer of training: Adding insight through social network analysis. Educ. Res. Rev. 2013, 8, 37-47. [CrossRef] 
48. Cadger, K.; Quaicoo, A.K.; Dawoe, E.; Isaac, M.E. Development interventions and agriculture adaptation: A social network analysis of farmer knowledge transfer in Ghana. Agriculture 2016, 6, 32. [CrossRef]

49. Chinowsky, P.; Taylor, J.E. Networks in engineering: An emerging approach to project organization studies. Eng. Proj. Organ. J. 2012, 2, 15-26. [CrossRef]

50. Dogan, S.Z.; Arditi, D.; Gunhan, S.; Erbasaranoglu, B. Assessing coordination performance based on centrality in an e-mail communication network. J. Manag. Eng. 2013, 31, 04014047. [CrossRef]

51. Ferriani, S.; Cattani, G.; Baden-Fuller, C. The relational antecedents of project-entrepreneurship: Network centrality, team composition and project performance. Res. Policy 2009, 38, 1545-1558. [CrossRef]

52. Liang, X.; Yu, T.; Guo, L. Understanding Stakeholders' Influence on Project Success with a New SNA Method: A Case Study of the Green Retrofit in China. Sustainability 2017, 9, 1927. [CrossRef]

53. Wambeke, B.W.; Liu, M.; Hsiang, S.M. Using Pajek and centrality analysis to identify a social network of construction trades. J. Constr. Eng. Manag. 2011, 138, 1192-1201. [CrossRef]

54. Lin, S.C. An analysis for construction engineering networks. J. Constr. Eng. Manag. 2014, 141. [CrossRef]

55. Eusgeld, I.; Kröger, W.; Sansavini, G.; Schläpfer, M.; Zio, E. The role of network theory and object-oriented modeling within a framework for the vulnerability analysis of critical infrastructures. Reliab. Eng. Syst. Saf. 2009, 94, 954-963. [CrossRef]

56. Zhang, Z.; Li, X.; Li, H. A quantitative approach for assessing the critical nodal and linear elements of a railway infrastructure. Int. J. Crit. Infrastruct. Prot. 2015, 8, 3-15. [CrossRef]

57. Yang, R.J.; Zou, P.X. Stakeholder-associated risks and their interactions in complex green building projects: A social network model. Build. Environ. 2014, 73, 208-222. [CrossRef]

58. Yu, T.; Shen, G.Q.; Shi, Q.; Lai, X.; Li, C.Z.; Xu, K. Managing social risks at the housing demolition stage of urban redevelopment projects: A stakeholder-oriented study using social network analysis. Int. J. Proj. Manag. 2017, 35, 925-941. [CrossRef]

59. Yang, R.J.; Zou, P.X.; Wang, J. Modelling stakeholder-associated risk networks in green building projects. Int. J. Proj. Manag. 2016, 34, 66-81. [CrossRef]

60. Delcea, C.; Cotfas, LA.; Paun, R.; Maracine, V.; Scarlat, E. A grey approach to online social networks analysis. In Transactions on Computational Collective Intelligence XXII; Springer: Berlin/Heidelberg, Germany, 2016; pp. 60-79.

(C) 2018 by the authors. Licensee MDPI, Basel, Switzerland. This article is an open access article distributed under the terms and conditions of the Creative Commons Attribution (CC BY) license (http:/ / creativecommons.org/licenses/by/4.0/). 